\title{
The Impact of Plastic Money Use on VAT Compliance: Evidence from EU Countries*
}

\author{
AMAKOE D. ALOGNON** \\ Georgia State University \\ ANTONIOS M. KOUMPIAS ${ }^{* * *}$ \\ University of Michigan-Dearborn \\ JORGE MARTÍNEZ-VÁZQUEZ ${ }^{* * * *}$ \\ Georgia State University
}

Received: June, 2020

Accepted: October, 2020

\begin{abstract}
This paper examines the impact of credit and debit card usage on VAT compliance using annual national level data for 26 European Union countries from 2000 to 2016. Exploiting spatiotemporal variation in plastic money use along with an instrumental variables approach, we find that a $1 \%$ increase in card payments reduces VAT gaps 0.51 percentage points whereas a $1 \%$ increase in cash withdrawals increases VAT gaps by 0.6 percentage points. Our contribution lies in using more adequate measures of VAT compliance gap and in accounting for potential confounders such as the ex-ante enforcement capacity of tax administrations.
\end{abstract}

Keywords: Tax compliance, Credit and debit card use, Plastic money, VAT gap, Tax administration.

JEL Classification: H26, K42.

\section{Introduction}

Over the recent decades, several countries around the world have introduced policies to limit cash use and incentivize the use of electronic means of payments in order to com-

\footnotetext{
* We thank José María Durán-Cabré and Alejandro Esteller-Moré, members of the research group responsible for the commissioned report by EU's Directorate General for Taxation and Customs Unions, for generous sharing of data. We are grateful for useful comments from the Editors, the Special Editors, anonymous reviewers and conference participants at the 2019 meetings of the Southern Economic Association that helped improve the study.

** ORCID ID: 0000-0003-4889-216X.

*** ORCID ID: 0000-0001-9792-5103.

***** ORCID ID: 0000-0003-2230-9204.
} 
bat money laundering, terrorism financing, and tax evasion. Despite the emergence of new risks for tax compliance associated with technological change, the use of cash remains central in money laundering (Europol, 2015). Cashless payments can influence VAT evasion by limiting the ability of small businesses and the self-employed to maintain tax-evading, parallel cash activities for which cash revenue is a necessary requirement (Clearly Morse et al., 2009). From 2005 to date, an increasing number of European countries have introduced upper limits to cash payments. In total, 17 out of $28 \mathrm{EU}$ member countries have implemented some sort of cash restriction as of September 2017. These cash restrictions range from EUR 500 in Greece to EUR 15,000 in Poland. In Spain, the government is contemplating to further reduce the current limit of cash payments (EUR 2,500 enacted in 2012 to EUR 1,000). The institutional response by the European Commission and the European Central Bank (ECB) to cash limiting legislations has been cautious. Recital 19 of Council Regulation (EC) No 974/98 on the introduction of the euro states that 'limitations on payments in notes and coins, established by Member States for public reasons, are not incompatible with the status of legal tender of euro banknotes and coins, provided that other lawful means for the settlement of monetary debts are available', a position maintained throughout the circulation of the euro as documented in ECB publications (e.g. ECB Opinions CON/2002/24, CON/2003/25, CON/2013/18, CON/2014/4, CON/2014/37, CON/2017/18, and CON/2020/17 among others). However, concerns have been raised that limitations on cash payments may constitute a breach of the legal tender status of cash. This has prompted recommendations for cash limit levels that are proportionate to the targeted money-laundering schemes. ${ }^{1}$

In some countries where these express cash restrictions are absent, the authorities require special reporting of cash payments. A marked example is the Form 8300 system in the United States which requires that any person engaged in a trade or business who receives more than $\$ 10,000$ in one transaction or several related transactions must file a cash payment report to the Internal Revenue Service (IRS). This system is used by the government to track tax evaders and individuals profiting from criminal activities.

Given all these cases of explicit or tacit cash restriction policies, it is of paramount importance to evaluate whether the belief that limiting cash transactions reduces tax evasion through increased use of electronic means of payments holds empirically. Has the proliferation in credit and debit card usage or the use of other electronic forms of payments (plastic money, hereafter) contributed to increase compliance with the consumption tax in the European Union (EU)? The link between VAT compliance and plastic money is justified by the fact that plastic money is the primary substitute to cash, and because plastic money transactions are traceable by tax authorities, they are less prone to tax evasion than cash transactions. The question deserves attention since the shift in norms and preferences regarding forms of payments presents an excellent opportunity for tax administrations to close the consumption tax compliance gap either directly by bringing previously unreported transactions into the tax net or by using newly generated third-party information (Kleven et al., 2011). Slemrod et al. (2017) investigate the effect of reporting requirements on sole proprietorship income obtained from electronic transactions such as credit card payments using confidential IRS tax return data. They estimate a small but robust increase in tax fil- 
ing and reported tax receipts for a subset of taxpayers more prone to behavioral response. Between 2000 and 2016, the average share of transactions cleared via plastic money in the 26 EU countries increased from EUR 34.6 billion to EUR 111.9 billion. In terms of nominal GDP, this represents a growth from $9.3 \%$ to $19.5 \%$. And, as noted by Auer et al. (2020), the COVID-19 lockdowns and rise in beliefs regarding viral transmission via cash may only compound the increasing trend toward plastic money use. ${ }^{2}$ At the same time, tax administrations in the EU have implemented a number of innovations aiming to capture "hard-totax" tax bases, which would appear have improved overall tax compliance but which have also confounded the potential impact of the shift in consumer preference in favor of plastic money. Therefore, up to now it remains unclear how important the role of plastic money has been in narrowing the observed tax compliance gap in the EU. Obtaining an answer to this question would be helpful also to other countries, especially developing countries, struggling with tax enforcement issues.

The seminal paper on the importance of third-party information in the context of the VAT by Pomeranz (2015) establishes the first-order deterrence effect of the paper trail generated by transactions between firms in Chile. An empirical literature has emerged with works closer to the research question of this study. First, Madzharova (2020) explores the impact of cash and card transactions on VAT collection efficiency in the EU member states from 2000 to 2010 and finds a statistically significant positive effect of card payments on tax revenue performance. Second, Hondroyiannis and Papaoikonomou (2020) analyze the effect of card payments on VAT revenue in 19 European Monetary Union (EMU) countries using panel quarterly information from 2003 to 2016. These authors find that a larger share of card payments in private consumption expenditure increases VAT revenue in the EU as a whole. Finally, Immordino and Russo (2018a) find some evidence of a positive effect of credit and debit card payments on VAT compliance in the EU while also showing that ATM cash withdrawals increase VAT evasion.

The first contribution of this study relative to Madzharova (2020) and Hondroyiannis and Papaoikonomou (2020) lies in the use of a less broad measure of VAT gap that is much more closely related to tax compliance. First, the dependent variable or observed outcome in our analysis is the VAT compliance gap as opposed to VAT Revenue Ratio (VRR) and VAT revenue used in pre-existing literature. This is computed as the difference between expected and realized tax revenues and may be interpreted as foregone tax revenues net of parameters that determine expected tax revenues such as tax rates. ${ }^{3}$ The VAT compliance gap is less susceptible to the inclusion or exclusion of observable factors that can be accounted for (manipulation bias) as well as unobservable confounding variation from other factors that influence revenue collection, such as changes in tax administration quality or enforcement capacity, which we may fail to capture fully (omitted variable bias), or partly (measurement error). The fact that our outcome is pre-determined by the reports of the Directorate General for Taxation and Customs Unions (DG TAXUD) safeguards against the arbitrary choice of explanatory variables that would introduce manipulation bias into our results. Furthermore, even observable factors such as exemptions and zero-rates cannot be easily accounted for when using aggregate (national) level data. In the prior literature, these correlations had been relegated to 
the error term leading to omitted variable bias, whereas in our study, they are captured by the outcome variable by definition. Even though Immordino and Russo (2018a) employ appropriate measures of VAT compliance gap, they estimate the effect of a single mean of payment at a time without accounting for variations in the other means of transactions. Furthermore, this study does not control for public authorities' efforts toward reducing the gap, which may overstate the estimates. These potential causes of omitted variable bias could lead to overestimate plastic money's role in reducing VAT gaps. Finally, with the availability of more recent data, our study extends the examination of plastic money's impact in the literature to a period during which it became much more prominent throughout the continent. From 2012 to 2016, the years for which we provide novel estimates, debit and credit card use increased by $43 \%$ (25.5\% as a fraction of GDP).

We exploit variation in time and space of credit and debit card usage across 26 EU member states from 2000-2016 using panel data and instrumental variable techniques to identify the effect of plastic money on VAT compliance. We find that an increase in the share of plastic money used for consumption expenditures is associated with a significant decrease in the VAT gap. The policy implications of our results are twofold. First, they highlight the role that technological, supply-side innovations such as the use of plastic money can play in assisting the compliance efforts of tax administrations around the world with limited capacity. Second, they demonstrate the limitations of some forms of third-party reporting in improving consumption tax compliance.

The remainder of the paper is organized as follows. The next section succinctly reviews the broad literature on the determinants of VAT compliance as well as the specific literature on the effect of plastic money on VAT compliance. Section 3 describes the data, provides some key summary statistics and delineates the empirical framework. Section 4 presents and discusses the results, while the last section concludes.

\section{Literature Review}

Several studies have empirically examined the economic, social, and institutional determinants of VAT compliance. While some studies analyzed the determinants of VAT revenues, rather than measures of VAT non-compliance per se, one needs to be cautious in comparing the results of these two groups of studies since VAT revenues and the VAT Revenue Ratio (VRR) reflect not only the effect of non-compliance but also the impact of policy choices on tax structure such as exemptions, reduced rates on certain transactions, etc. We first review studies on the determinants of VAT compliance gap to circumscribe the universe of potential control variables and then focus on papers that investigate the effect of card payments on VAT revenue or measures of VAT efficiency.

In a pioneering study, Agha and Haughton (1996) constructed an index of VAT compliance for a cross-section of 17 OECD countries in 1987 and regressed it on characteristics of the countries and their VAT rates. The index was set as the ratio of actual VAT to potential 
VAT, analogous to the VRR. They find that a higher VAT rate is associated with lower compliance, and that compliance is considerably lower with multiple VAT rates. The study also suggests that VAT compliance increases the longer VAT has been introduced.

Studying the factors that determine VAT fraud in Italy from 1982 to 2001, Otranto et al. (2003) find that VAT evasion is positively affected by variables such as the GDP, the share of the fiscal burden, and the ratio of gross profits over value added. However, it is negatively associated with the number of taxpayers audited in the previous year by public authorities. Christie and Holzner (2006) examine data for 29 European countries over the period 20002003. Their analysis reveals that higher VAT rates reduce VAT compliance whereas greater judicial and legal effectiveness improve compliance.

Another seminal study devised to quantify and analyze the VAT gap was the one commissioned by the DG TAXUD of the European Commission and executed by Reckon (2009). Investigating the relationship between the estimated VAT compliance gap and some economic and institutional variables, the report reveals that VAT gaps were significantly higher in countries with higher perceived levels of corruption. However, the study does not find robust statistical evidence of an association between the compliance gap and economic variables such as the sectoral composition of the economy, the GDP per capita, the level of taxation (VAT standard rate and theoretical VAT liability as a proportion of GDP), etc. One methodological issue with the Reckon report is that it relies on a random effect estimator which assumes that unobserved country-specific differences that determine taxpayer compliance are random, and thus uncorrelated to the explanatory variables of interest. This approach may suffer from omitted variable bias and therefore unlikely to produce reliable estimates of the determinants of the VAT gap. Aware of this possible limitation, the recent study commissioned by the DG TAXUD and conducted by the Center for Social and Economic Research (CASE) used a fixed effect estimation technique to quantify and analyze the drivers of the VAT compliance in European countries. The final report released in 2018 suggests that the productive structure of the economy affects the VAT compliance gap with the biggest effect due to the retail sector (Poniatowski et al., 2018). This means that the larger the share of the retail sale sector in the economy, the larger the gap is. It also reveals a positive correlation between unemployment as a proxy of liquidity constraints and the level of the compliance gap. However, the report does not find a consistent effect of the scale of the tax administration on the VAT compliance gap. From the regressions which include subsets of the explanatory variables, the authors find that higher administration costs lead to lower compliance gaps. However, once all the explanatory variables are introduced in the regression analysis, the study finds a positive, U-shaped association between the scale of the tax administration and the compliance gap, suggesting that higher administration expenditures hinder tax compliance up to a certain threshold and then become productive. In the same vein, Lago-Peñas and Lago-Peñas (2010) examine the determinants of tax morale in a multilevel analysis in the EU. They find that tax morale is a function of individual and contextual level variables. They show that tax morale in European countries varies systematically, on the one hand, with socio-demographic characteristics (age, gender, education level, and religion), personal financial experiences (income levels and self-employment), political attitudes (satisfaction with democracy, trust in politicians, and 
measures to reduce differences in income), and on the other hand, with regional GDP and tax arrangements. Due to the close correlation between tax morale and VAT compliance, we include predictors of tax morale in our empirical analysis given that tax morale is not available in annual frequency for all the countries in the study sample.

Turning to studies that examined the effect of card payments on VAT revenue or VAT efficiency measures, a few works closely related to this paper are those by Madzharova (2020), Hondroyiannis and Papaoikonomou (2017, 2020), and Immordino and Russo (2018a). Hondroyiannis and Papaoikonomou (2017) analyze the effect of card payments on VAT revenue after Greek authorities imposed restrictions on cash withdrawals in July 2015. They find that a 1 percentage point increase in the share of credit card payments in private consumption results in approximately $1 \%$ increase in VAT revenue. Hondroyiannis and Papaoikonomou (2020) examine the same relationship using quarterly panel data for the 19 Euro area economies from 2003-2016 to find that an increasing share of credit card payments in private consumption expenditure improves VAT revenue in the EU. Moreover, they show that gains from increased credit card use are decreasing in baseline card use and revenue efficiency levels while increasing in the share of self-employed individuals in the labor force with the largest gains reported for Greece and Italy. Madzharova (2020) investigates the impact of cash and card transactions on VAT collection efficiency in the EU member states from 2000 to 2010. She finds statistically significant improvements on tax revenue performance from increased use of card payments and that cash usage has a consistent negative effect on VAT efficiency. A potential concern with this study is the use of observed VAT revenue or (VRR) as the measure of tax revenue efficiency without controlling in their estimations for contemporaneous tax policy changes of importance such as the enforcement capacity of the tax administration. This situation can lead to omitted variable bias in the estimates reported in these papers. In fact, tax fraud and tax evasion account for only a fraction of the entire VAT gap. The remaining portion of the total gap is due to tax structure policy decisions -the legal gap- which varies widely across space and time. In a nutshell, the measures of tax compliance efficiency used in these studies may be limiting their ability to trace out the effect of plastic money on tax compliance since the policy gap varies widely within a country and across countries. In this respect, Madzharova (2020) acknowledges that, ideally, one should use the compliance ratio. The present paper has the advantage of using VAT compliance gaps computed through the joint effort of a dozen tax administrations and research institutions in for a study commissioned by the DG TAXUD in 2015 on the VAT gap in the EU member states. This alternative outcome is also preferred by Immordino and Russo (2018a), the most closely related study to this paper. Even though an appropriate measure of VAT compliance gap is used in it, evaluating the effect of one mean of payments (either cash or card) at a time while abstracting from the other transaction method can pose the problem of omitting a relevant regressor if the two types of transactions are strongly correlated. In fact, economic agents do not perform only card payments or only cash transactions. The majority of agents does both and both are present at the same time in the economy and are related (complements or substitutes). Hence, the effect of the use of one means of payments on the compliance gap should be conditional on the use of the other one. Moreover, the study does not account for ex ante efforts made by public authorities to reduce the VAT gap, which can cast doubt on its estimates. For example, 
stronger tax administrations may advocate in favor of severe cash restriction policies in order to curb the gap. This can lead, once again, to omitted variable bias issue in their analysis. Finally, our study also provides an update of Immordino and Russo (2018a) by extending the panel by four more years during which plastic money use increased markedly.

\section{Data and Empirical Analysis}

This section first describes the data utilized in this study and presents some key summary statistics on VAT compliance gap and plastic money use in the EU. Then it discusses the methodology employed to tease out the effect of plastic money use on the VAT compliance gap.

\subsection{Data}

The data utilized in this study stem from several sources and cover the period 2000 to 2016. Our empirical exercise focuses on the effect of the proliferation in credit and debit card use on consumption tax compliance, namely VAT compliance. The measures of VAT gap utilized are the VAT gap in EUR, the VAT gap as share of GDP, and the VAT gap as share of Value-Added Total Tax Liability (VTTL), which proceed from the 2013 and 2018 final reports on the VAT gap in the EU member states (Poniatowski et al., 2018). These data are available for all the 26 countries from 2000 to 2016.

Our first key explanatory variable is the value of card transactions by all cards issued in the reporting country as a share of GDP. Card payments cover the period 2000-2016 for all the countries but Bulgaria, Luxembourg, and Slovakia for which they are available from 2001, and Spain where they start from 2002. The second main regressor is the ratio of cash withdrawals to GDP. The GDP data proceed from the Eurostat database, while card payments and cash transactions are drawn from the ECB data warehouse. We use ATM cash withdrawals (pertaining to cards issued in the reporting country) which have fewer missing observations to approximate cash transactions. ${ }^{4}$ In lieu of cash transactions, we use in some specifications the relative size of the shadow economy in the GDP as computed by Medina and Schneider (2018). We also obtain from the ECB information on the number of ATM per million inhabitants.

Expected efforts made by the tax administration to close the VAT gap ex ante can also have a deterrent effect on private agents' tax compliance behavior. These efforts can be driven by the scale of the tax administration (measured as the ratio of total administrative costs as a percent of GDP), the share of information and technology expenditures in total administrative costs, as well as the level of public indebtedness measured by the ratio of public deficit to GDP. We therefore account for these 3 variables to proxy the effect of the tax administration on voluntary tax compliance, controlling for them in a lagged form to reflect expectations. The data on the scale of the tax administration and IT expenditures are obtained from the OECD data bank while the ratio of public deficit to GDP comes from Eurostat. 
One factor supposed to shape tax morale, and thus potentially tax compliance, is age structure. In fact, the literature on tax morale finds that older people exhibit higher tax morale, which is commonly explained as being more aware of the benefits of adopting a prosocial behavior (Koumpias et al., 2020). The variable used to proxy tax morale is the share of people over 50 years old in the population obtained from Eurostat database. In addition, the less effective use of public resources by the government, the perception of private economic agents about the poor performance of public authorities, and liquidity constraints can create incentives to free ride and avoid tax payment (Godin and Hindriks, 2015). To account for the quality of government, this paper utilizes the World Bank's government effectiveness indicator. Besides, we control for the unemployment rate obtained from Eurostat to proxy for liquidity constraints and the business cycle. We also account for over time cross-country differences in payment habits that depend on the level of economic development by controlling for the GDP per capita. Tax evasion can also depend on the productive structure of the economy in the sense that some sectors (like wholesale and retail trade) may be more prone to tax evasion than others (such as real estate). Therefore, we control for the percentage share of the following sectors in the gross value-added (VA): wholesale and retail trade, transport, accommodation and food service activities, as well as real estate, construction, industry, information and communication, and art and entertainment. Sectors that are exempted from VAT, namely health, education, or financial services, are excluded. These series as well as those on GDP per capita and population size are obtained from the Eurostat data bank. Finally, private agents' tax compliance behavior can be affected by prevailing VAT rates. However, VAT rates do not change very often. Hence, their impact on the compliance gap would be subsumed in country-specific heterogeneities. Following Poniatowski et al. (2018) we control instead for the dispersion of tax rates (within a country), which provide incentives and opportunities for evasion, using data generously provided by Poniatowski et al. (2018). Some of the control variables have missing values for some countries in specific years, giving rise to an unbalanced panel covering the period 2000-2016. Table A.1 in the Appendix provides summary statistics and data sources for all variables employed.

\subsection{Descriptive Statistics}

Figure 1 below is a binned scatterplot of the VAT gaps and plastic money use between 2000 and 2016; for each country studied, it plots the estimated average VAT gap in each plastic money usage bin (20 bins specified). ${ }^{5}$ It is used to succinctly illustrate the relationship between VAT gap levels and plastic money use. Despite substantial heterogeneity, it provides first evidence of a negative correlation between VAT gaps and plastic money use. This association may also be the consequence of third factors that jointly impacted VAT gaps and plastic money use. Nevertheless, it highlights the fact that the proliferation of plastic money coincided with a reduction in VAT gaps. Furthermore, to highlight the differential relationship between plastic money use and VAT gaps across different blocs of EU countries, we split the sample by whether or not a country is classified as a Central and Eastern European (CEE) country according to the OECD. This illustrates that the negative relationship of interest is relatively more pronounced for CEE countries which may be attributed to lower baseline plastic money usage levels in these countries. 
Figure 1

VAT GAPS AND PLASTIC MONEY USE IN CEE AND NON-CEE COUNTRIES

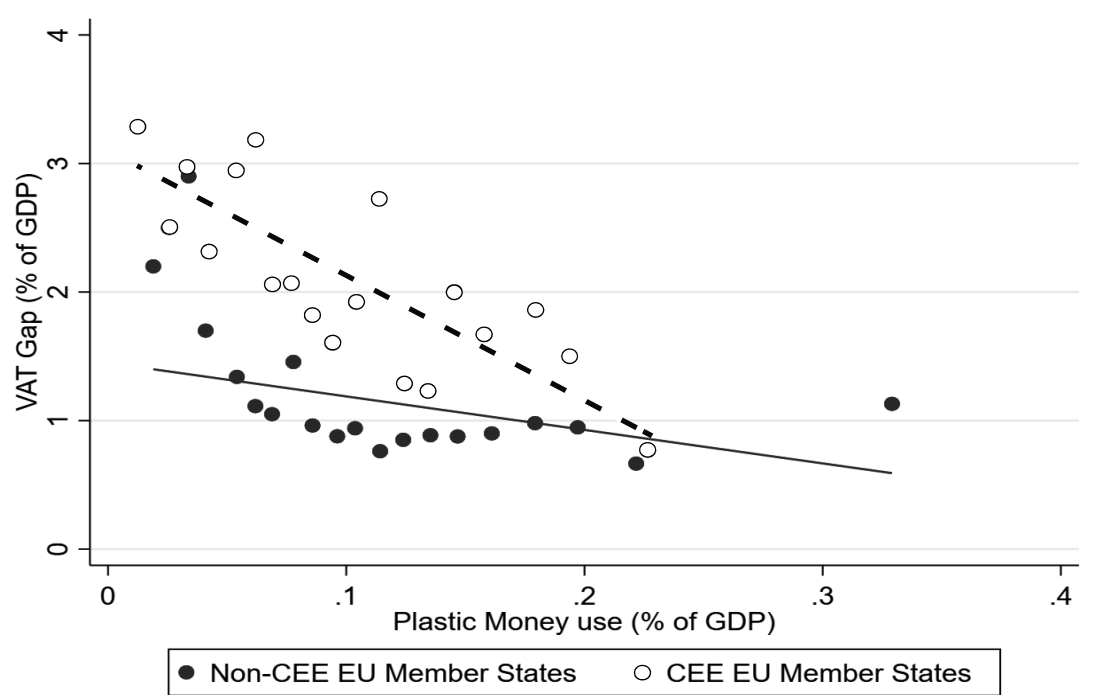

Note: Binned scatterplot of VAT gaps and plastic money use by Central Eastern European (CEE) and non-CEE EU member states (Stepner, 2014).

\subsection{Empirical Strategy}

To identify the effect of plastic money on VAT compliance, this study exploits spatiotemporal variations in plastic money usage over time across different EU member states in a fixed effect (FE) panel regression framework. An advantage of the FE estimation technique is that it allows country-specific time-invariant unobservables to be correlated with the explanatory variables. The econometric model can be specified as follows:

$$
Y_{i t}=\beta_{0}+\beta_{1} W_{1 i t}+\beta_{2} W_{2 i t}+\boldsymbol{X}_{i t} \boldsymbol{\alpha}+\mu_{i}+\tau_{t}+\epsilon_{i t}
$$

where $i$ denotes the country, and $t$ represents the year; $Y_{i t}$ represents the outcome (VAT gap, VAT gap as share of GDP, and VAT gap as share of VTTL); $W_{1 i t}$ is the main explanatory variable, defined as the logged total value of residents' card payments as share of GDP; $W_{2 i t}$ represents the logged ATM cash withdrawals as share of GDP; $\boldsymbol{X}_{i t}$ denotes the set of control variables (incentives created by the tax administration, government effectiveness, productive structure of the economy, tax morale, GDP per capita) discussed above in subsection 3.1. We include these regressors as they have been pre-identified as determinants of VAT gaps in the literature ((Poniatowski et al., 2018). Some control variables, namely cash withdrawals as share of GDP, population and GDP per capita, enter the model in their logarithm form. The term $\mu_{i}$ captures time-invariant country-specific heterogeneities that affect tax compliance, while $\tau_{t}$ accounts for year-specific effects such as macroeconomic factors that affect indiffer- 
ently tax compliance in the European economies under study; $\epsilon_{i t}$ represents the idiosyncratic disturbance, while $\beta_{1}$ and $\beta_{2}$ identify respectively the effect of plastic money use and cash transactions on tax compliance. Standard errors are clustered at the country level to account for serial within-country correlation in the data.

A potential concern with the model specified by equation (1) is that the choice to use a specific means of transactions may be endogenous to tax evasion. Immordino and Russo (2018b) propose a bargaining model where buyers may reach an agreement with sellers to engage in collaborative tax evasion for a reduced transaction price. To overcome this potential threat to identification, we resort to an instrumental variable (IV) approach. For the IV technique to be valid, a number of tests needs to be performed. First, one needs to test if the instruments are exogenous, i.e. if they are uncorrelated with the error process in the structural equation. In our context, this implies that each of these instruments must affect plastic money use without itself being influenced by the VAT gap. Moreover, each instrument must affect the VAT gap only through its effect on the payment method. A rejection of the null hypothesis of the Hansen J statistic of overidentification test casts doubt on the validity of the instruments. Second, we need to check if the instruments are relevant, i.e if they are sufficiently strong in predicting the endogenous regressors. This is obtained through the test of weak identification which compares a Wald-type F statistic to critical values tabulated by Stock-Yogo (2005). A rejection of the null hypothesis suggests that the model is not weakly identified. Since we allow for heteroskedastic errors, the Cragg-Donald Wald F statistic is no longer valid, and one needs to use instead the Kleibergen-Paap Wald rank F statistic. This test is important because in the presence of weak instruments, the loss of precision is severe, and IV estimates may even perform more poorly than the ones obtained via Ordinary Least Squares (OLS). Hence, third, we need to assess whether the potentially endogenous regressors should be treated as exogenous given the instruments. Under homoskedasticity, this is equivalent to the Hausman test of IV estimates versus OLS estimates.

Following Immordino and Russo (2018a), we instrument card and cash payments by the number of ATM per million inhabitants and the number of fixed broadband internet connections per inhabitant. In addition, we employ the number of bank branches per $100 \mathrm{~km}^{2}$ (bank branch density) as a third instrumental variable. The choice of the number of ATMs as instrument is justified by the fact that the availability of ATM terminals can stimulate cash withdrawals. It is likely that less direct card transactions are recorded where there are more ATMs available since it is easier to get cash. Besides, it has been documented that ATM development is mainly due to technological advances that curb their installation and management costs, ruling out the possibility that the diffusion of ATMs is a response to tax evasion. Finally, we cannot conceive any direct effect of ATM prevalence on tax compliance other than through its facilitation of cash withdrawals (Humphrey et al., 2006). Therefore, we expect the number of ATMs per million inhabitants to be negatively and positively associated with card payments and ATM cash withdrawals, respectively, as they reflect individual demand for cash. We use bank branch density to decompose the differential supply- and demand-side effects of access to banking services. Closely related in nature as another proxy of banking services availability, it is reasonable to assume bank branch density to be also positively associated with demand for cash and, subsequently, ATM cash withdrawals. We 
posit that bank branch density is additionally influenced by supply-side effects in the form of banking industry reorganization with the advent of e-banking, not VAT gaps. Thus, we expect bank branch density to be also positively associated with the share of card payments as a percent of the GDP. Similar arguments hold for broadband internet connections. The use of broadband internet connections as an instrument is motivated by the fact it facilitates electronic transactions which require cashless payments. Therefore, more broadband connections would induce more transactions cleared via plastic money and less demand of cash for transactions. Consequently, a positive and negative relationship between plastic money usage and cash usage, respectively, is expected. As in the case of ATM development, since broadband connections mainly hinge on the availability of the infrastructure in a given country, which, in turn, is not likely correlated with VAT evasion. Further, the exclusion restriction requires that any effect of variations in broadband internet connections affects VAT gaps solely via plastic money use. This is a tenable assumption since more broadband internet connections directly affect VAT gaps by requiring cashless transactions whereas any effect on tax enforcement is fully captured in the calculation of the VAT gaps, by design (Immordino and Russo, 2018a). As stated earlier, the main difference with Immordino and Russo (2018a) lies in the fact that the authors considered one form of payments at a time, yet both can be endogenous. Hence, in the first stage, both the logged card payments and cash withdrawals as share of GDP are regressed on the set of instruments and control variables which includes country and year unobserved heterogeneities. In order to test for overidentification, we include the interaction term of the number of ATMs per million inhabitants with the broadband internet connection and the interaction term of the number of ATMs per million inhabitants with bank branches. The first interaction term is justified by the fact that card payments are likely determined by the combination of the two means, whereas the second interaction term accounts for non-commercial ATM attached to a bank branch as opposed to standalone ATMs that are more susceptible to variations in demand for cash. This intuition is confirmed by the results of the first stage IV regression reported in Table 3.

\section{Results}

The results indicate a strong correlation between card payments and cash withdrawals. Therefore, as stressed earlier, the concern regarding overestimation of the impact of plastic money use due to omitted variable bias in prior studies is valid. We then examine a regression model that accounts for both means of transactions as well as tax enforcement endeavors of public administrations. Table 1 displays the results of the cross-country fixed effect panel regressions. We consider three different variations of the outcome, VAT gap. In columns (1)(2), (3)-(4), and (5)-(6), the dependent variables are respectively the logarithm of the VAT gap, the VAT gap as percent of GDP and the VAT gap as percent of VTTL. Our preferred outcome variable is the VAT gap as share of GDP since we can similarly normalize the key independent variable by GDP. Columns (2), (4), and (6) report the estimates of regressions that include the size of the shadow economy rather than ATM cash withdrawals. Table A2 in appendix shows the regression results when we include an indicator for CEE countries and its interaction with card payment transactions as additional explanatory variables. 
Table 1

FIXED-EFFECT PANEL REGRESSION ESTIMATES OF VAT GAP ON PLASTIC MONEY USE

\begin{tabular}{|c|c|c|c|c|c|c|}
\hline \multirow[b]{2}{*}{$\begin{array}{l}\log (\text { Card payments as \% } \\
\text { of GDP })\end{array}$} & \multicolumn{2}{|c|}{ Log (VAT gap) } & \multicolumn{2}{|c|}{$\begin{array}{c}\text { VAT gap as \% of } \\
\text { GDP }\end{array}$} & \multicolumn{2}{|c|}{$\begin{array}{l}\text { VAT gap as \% of } \\
\text { VTTL }\end{array}$} \\
\hline & $\begin{array}{c}0.0482 \\
(0.137)\end{array}$ & $\begin{array}{l}-0.0306 \\
(0.087)\end{array}$ & $\begin{array}{l}0.1030 \\
(0.155)\end{array}$ & $\begin{array}{c}0.0736 \\
(0.150)\end{array}$ & $\begin{array}{l}0.5584 \\
(1.566)\end{array}$ & $\begin{array}{r}-0.1474 \\
(1.631)\end{array}$ \\
\hline $\begin{array}{l}\log (\text { ATM cash withdraw- } \\
\text { als as } \% \text { of GDP) }\end{array}$ & $\begin{array}{l}-0.0887 \\
(0.224)\end{array}$ & & $\begin{array}{l}-0.1500 \\
(0.140)\end{array}$ & & $\begin{array}{l}-2.5835 \\
(1.654)\end{array}$ & \\
\hline $\begin{array}{l}\text { Size of the shadow } \\
\text { economy }\end{array}$ & & $\begin{array}{l}-0.0976^{* *} \\
(0.045)\end{array}$ & & $\begin{array}{l}-0.0187 \\
(0.040)\end{array}$ & & $\begin{array}{l}-0.2522 \\
(0.489)\end{array}$ \\
\hline $\begin{array}{l}\text { Share of whole and retail } \\
\text { sale in VA }(\%)\end{array}$ & $\begin{array}{l}-0.0148 \\
(0.030)\end{array}$ & $\begin{array}{l}-0.0316 \\
(0.025)\end{array}$ & $\begin{array}{l}-0.0562 \\
(0.056)\end{array}$ & $\begin{array}{l}-0.0567 \\
(0.049)\end{array}$ & $\begin{array}{c}0.0526 \\
(0.391)\end{array}$ & $\begin{array}{l}-0.0503 \\
(0.332)\end{array}$ \\
\hline $\begin{array}{l}\text { Share of real estate in VA } \\
(\%)\end{array}$ & $\begin{array}{l}-0.0614 \\
(0.055)\end{array}$ & $\begin{array}{l}-0.0478 \\
(0.048)\end{array}$ & $\begin{array}{l}-0.0195 \\
(0.056)\end{array}$ & $\begin{array}{l}-0.0128 \\
(0.060)\end{array}$ & $\begin{array}{l}-0.1995 \\
(0.510)\end{array}$ & $\begin{array}{l}-0.1785 \\
(0.554)\end{array}$ \\
\hline Share of arts in VA (\%) & $\begin{array}{l}-0.0754 \\
(0.064)\end{array}$ & $\begin{array}{l}-0.0394 \\
(0.050)\end{array}$ & $\begin{array}{l}0.0347 \\
(0.055)\end{array}$ & $\begin{array}{c}0.0520 \\
(0.054)\end{array}$ & $\begin{array}{r}0.0372 \\
(0.530)\end{array}$ & $\begin{array}{l}0.1799 \\
(0.494)\end{array}$ \\
\hline Dispersion of tax rates & $\begin{array}{l}-0.7873 \\
(1.814)\end{array}$ & $\begin{array}{l}-1.9653 \\
(2.005)\end{array}$ & $\begin{array}{l}2.5325 \\
(1.940)\end{array}$ & $\begin{array}{l}1.6008 \\
(2.223)\end{array}$ & $\begin{array}{c}26.1645 \\
(18.965)\end{array}$ & $\begin{array}{r}14.9402 \\
(22.419)\end{array}$ \\
\hline Unemployment rate & $\begin{array}{r}0.0241 \\
(0.014)\end{array}$ & $\begin{array}{l}0.0423^{* *} \\
(0.018)\end{array}$ & $\begin{array}{l}0.0554^{* *} \\
(0.023)\end{array}$ & $\begin{array}{l}0.0512^{*} \\
(0.025)\end{array}$ & $\begin{array}{l}0.4771^{* *} \\
(0.206)\end{array}$ & $\begin{array}{l}0.4600^{* *} \\
(0.211)\end{array}$ \\
\hline Age structure & $\begin{array}{c}0.0750 \\
(0.051)\end{array}$ & $\begin{array}{c}0.0486 \\
(0.044)\end{array}$ & $\begin{array}{l}0.1367^{* *} \\
(0.059)\end{array}$ & $\begin{array}{c}0.0949^{*} \\
(0.054)\end{array}$ & $\begin{array}{c}1.0273^{*} \\
(0.561)\end{array}$ & $\begin{array}{c}0.6665 \\
(0.492)\end{array}$ \\
\hline Deficit to GDP ratio & $\begin{array}{l}-0.0297 \\
(0.019)\end{array}$ & $\begin{array}{l}-0.0220 \\
(0.017)\end{array}$ & $\begin{array}{l}-0.0323^{*} \\
(0.018)\end{array}$ & $\begin{array}{l}-0.0292 \\
(0.019)\end{array}$ & $\begin{array}{l}-0.3296^{*} \\
(0.176)\end{array}$ & $\begin{array}{l}-0.2784 \\
(0.174)\end{array}$ \\
\hline Log(GDP per capita) & $\begin{array}{c}0.9493^{*} \\
(0.463)\end{array}$ & $\begin{array}{c}0.7085 \\
(0.502)\end{array}$ & & & $\begin{array}{c}1.8887 \\
(3.817)\end{array}$ & $\begin{array}{c}0.4060 \\
(5.200)\end{array}$ \\
\hline Country FE & Yes & Yes & Yes & Yes & Yes & Yes \\
\hline Year FE & Yes & Yes & Yes & Yes & Yes & Yes \\
\hline Observations & 412 & 411 & 412 & 411 & 412 & 411 \\
\hline R-squared & 0.317 & 0.363 & 0.314 & 0.264 & 0.286 & 0.227 \\
\hline Number of countries & 26 & 26 & 26 & 26 & 26 & 26 \\
\hline
\end{tabular}

Notes: The following regressors are omitted from presentation: share of construction in VA, share of industry in VA, share of telecommunications in VA, $\log$ (population) and the constant term. Robust standard errors appear in parentheses. ${ }^{* * *} \mathrm{p}<0.01,{ }^{* *} \mathrm{p}<0.05,{ }^{*} \mathrm{p}<0.1$.

The OLS estimates reported in Table 1 suggest that plastic money use does not significantly affect VAT compliance in the EU. This result is consistent with the OLS results of Immordino and Russo (2018a) who find no impact of card payments on VAT collection efficiency. However, this result is not in line with Hondroyiannis and Papaoikonomou (2020) who find that the 
share of card payments in private consumption expenditure improves VAT tax compliance in the 19 Euro area economies. Next, we find that the unemployment rate has a large, positive and very precise association with all measures of VAT gap. Again, this is not surprising given that the unemployment rate is directly related to the size of the shadow economy which has been typically found to increase tax evasion and thus the tax compliance gap. Lastly, the naive OLS estimates suggest a positive and weakly statistically significant relationship between the GDP per capita and the level VAT gap. However, this is not confirmed when using the VAT gap as share of VTTL. It is not immediately obvious why; a potential explanation might be a common stochastic trend shared by these two macroeconomic aggregate time series.

To tackle the aforementioned potential endogeneity issue, we resort to an IV approach using the prevalence of ATM, broadband internet connections, and geographical density of bank branches in a country as well as the interaction term of the number of ATMs per million inhabitants with each of the other instruments. Table 2 reports the estimates of the first stage regressions with the results of the identification tests.

Table 2

FIRST STAGE IV REGRESSION RESULTS

\begin{tabular}{lcc}
\hline & $\begin{array}{c}\text { Log (Card payments } \\
\text { over GDP) }\end{array}$ & $\begin{array}{c}\text { Log (ATM cash } \\
\text { withdrawals over GDP) }\end{array}$ \\
\hline Log(\# ATM per million inhabitants) & $0.270^{* * * *}$ & $0.684^{* * *}$ \\
Broadband & $(0.0797)$ & $(0.0803)$ \\
& $0.0586^{* * *}$ & $-0.0491^{* *}$ \\
Log(\# ATM per million inhabitants)* & $(0.0143)$ & $(0.0199)$ \\
Broadband & $-0.00944^{* * *}$ & $0.00667^{* *}$ \\
Bank Branches per 100 km ${ }^{2}$ & $(0.00207)$ & $(0.00294)$ \\
& $0.103^{*}$ & $0.143^{* *}$ \\
Log(\#ATM per million inhabitants)*Bank & $(0.0605)$ & $(0.0627)$ \\
Branches per 100 km ${ }^{2}$ & -0.00912 & $-0.0211^{* *}$ \\
\hline R-squared & $(0.00899)$ & $(0.00952)$ \\
Observations & 0.948 & 0.885 \\
Number of countries & 400 & 395 \\
Country FE & 25 & 25 \\
Year FE & Yes & Yes \\
\hline
\end{tabular}

Notes: The following regressors are omitted from presentation: share of whole and retail sale in VA, share of real estate in VA, share of construction in VA, share of industry in VA, share of telecommunications in VA, share of arts, dispersion rate, unemployment rate, age structure, deficit to GDP ratio, $\log$ (population), $\log$ (GDP per capita), and the constant term. Robust standard errors appear in parentheses. ${ }^{* * *} \mathrm{p}<0.01,{ }^{* *} \mathrm{p}<0.05,{ }^{*} \mathrm{p}<0.1$.

The population density of ATMs and, to a lesser extent, the geographical density of bank branches are also predictive of card use which could indicate banking services availability. As 
expected, broadband internet connections, as an indicator of a digital society, are positively linked to plastic money usage and negatively linked to cash withdrawals. However, as ATM density (broadband internet connections) increases, the positive impact of broadband (ATM density) on card use becomes less pronounced. Conversely, the negative effect of broadband internet connections on cash withdrawals is weaker when more ATM per million inhabitants are available. Not surprisingly, ATM and bank branch density are positively related to cash withdrawals. The relatively stronger association between ATM density and cash withdrawals confirms our conjecture that ATM density reflects demand for cash whereas bank branch density may be also driven by supply-side changes in the banking industry. As more bank branches (ATMs) are introduced though, the effect of ATM (bank branch) density on cash withdrawals becomes negative, and vice versa. Still, the magnitude of the estimated negative effect of the interaction term is relatively smaller than the positive effects estimated for each of their factors. Thus, this small effect could reflect market saturation and the adverse influence of increasing banking services on cash withdrawals that does not reverse the main effects. Finally, a null effect of branch density (ATM density) on card use is recovered when ATM density (branch density) rises.

The Hansen $\mathrm{J}$ test of overidentification fails to reject the null hypothesis of overidentification of the models in all the three columns at the conventional critical level of 5\%. This suggests that the instruments are valid. Moreover, the Kleibergen-Paap Wald rank F statistics compared to the Stock-Yogo weak identification test critical values suggest that the instruments are relatively strong. Finally, the endogeneity tests conditional on the instruments reject in all cases the null hypothesis of exogeneity of plastic money use and cash transactions, and therefore IV estimates should be preferred.

Table 3 shows the results of the second stage IV regressions. Conversely to the naïve OLS estimates, it appears that card payments are somewhat contributing to reducing tax evasion. In fact, column (3) reports a strong negative effect of plastic money use on VAT evasion at the 5\% significance level while column (2) shows a less strong effect (significant at the $10 \%$ level) of card payments on tax compliance. Specifically, we find that a $1 \%$ increase in card payments as share of GDP translates to a 0.51 percentage points smaller VAT gap as percent of GDP. This suggests that doubling the share of card transactions would halve the share of VAT gap. As for the VAT gap as a percent of VTTL, the estimates show that a $1 \%$ rise in plastic money use is associated with a 7.6 percentage points improvement in compliance. Therefore, ceteris paribus, to halve the share of the VAT gap in the value-added total tax liability, plastic money use needs to increase by roughly 6.6\%. The IV regression also reveals a strong positive and consistent effect of cash withdrawals on tax evasion across all the specifications. The results in column (2) indicates that a $1 \%$ rise in the share of cash withdrawals in output would lead to an approximately $0.43 \%$ increase in the VAT gap or roughly $0.6 \%$ as percent of GDP. When expressed as a percent of the VTTL, a $1 \%$ increase in cash withdrawals is linked to a 4.3 percentage points increase in evasion. However, it should be noted that the estimated effect for the log specification in column (1) is negative yet not significant. A potential explanation for the difference in statistical significance to columns (2) and (3) is the fact the outcome in (1) is not normalized. Still, this imprecisely estimated, negative effect may not be entirely dismissed as null as it is not centered around zero. Findings are largely in 
line with Immordino and Russo (2018a) who reported that plastic money use improves VAT compliance. These results are in line with previous studies which found that cash withdrawals foster tax evasion (Immordino and Russo, 2018a; Madzharova, 2020).

Table 3

SECOND STAGE FE IV REGRESSION OF VAT GAP ON PREDICTED PLASTIC MONEY USE AND CASH WITHDRAWALS

\begin{tabular}{|c|c|c|c|}
\hline & Log (VAT gap) & $\begin{array}{l}\text { VAT gap as \% of } \\
\text { GDP }\end{array}$ & $\begin{array}{c}\text { VAT gap as \% of } \\
\text { VTTL }\end{array}$ \\
\hline Log (Card payments as \% of GDP) & $\begin{array}{l}-0.3387 \\
(0.274)\end{array}$ & $\begin{array}{l}-0.5107^{*} \\
(0.290)\end{array}$ & $\begin{array}{l}-7.6172^{* *} \\
(3.362)\end{array}$ \\
\hline Log (Cash withdrawals as \% of GDP) & $\begin{array}{l}0.4259^{* *} \\
(0.168)\end{array}$ & $\begin{array}{l}0.5951^{* * * *} \\
(0.192)\end{array}$ & $\begin{array}{l}4.3074^{* *} \\
(1.840)\end{array}$ \\
\hline Share of whole and retail sale in VA (\%) & $\begin{array}{l}-0.0195 \\
(0.026)\end{array}$ & $\begin{array}{l}-0.0502 \\
(0.036)\end{array}$ & $\begin{array}{c}0.1004 \\
(0.279)\end{array}$ \\
\hline Share of real estate in VA $(\%)$ & $\begin{array}{l}-0.0956^{* *} \\
(0.043)\end{array}$ & $\begin{array}{l}-0.0685^{*} \\
(0.039)\end{array}$ & $\begin{array}{l}-0.7450^{* *} \\
(0.363)\end{array}$ \\
\hline Share of arts in VA $(\%)$ & $\begin{array}{l}-0.0589 \\
(0.060)\end{array}$ & $\begin{array}{r}0.0525 \\
(0.062)\end{array}$ & $\begin{array}{r}0.2820 \\
(0.610)\end{array}$ \\
\hline Dispersion rate & $\begin{array}{l}-0.3296 \\
(1.392)\end{array}$ & $\begin{array}{l}4.1564^{* * *} \\
(1.387)\end{array}$ & $\begin{array}{l}38.0624^{* * *} \\
(14.426)\end{array}$ \\
\hline Unemployment rate & $\begin{array}{c}0.0123 \\
(0.013)\end{array}$ & $\begin{array}{l}0.0350^{* * *} \\
(0.017)\end{array}$ & $\begin{array}{l}0.2963^{*} \\
(0.160)\end{array}$ \\
\hline Age structure & $\begin{array}{c}0.0347 \\
(0.036)\end{array}$ & $\begin{array}{c}0.0743 \\
(0.046)\end{array}$ & $\begin{array}{c}0.3829 \\
(0.406)\end{array}$ \\
\hline Deficit to GDP ratio & $\begin{array}{l}-0.0282^{* *} \\
(0.014)\end{array}$ & $\begin{array}{l}-0.0298^{* *} \\
(0.015)\end{array}$ & $\begin{array}{l}-0.2804^{*} \\
(0.144)\end{array}$ \\
\hline Log (Population) & $\begin{array}{l}-2.3343 \\
(1.453)\end{array}$ & $\begin{array}{l}-1.5041 \\
(1.325)\end{array}$ & $\begin{array}{l}-19.2840 \\
(12.295)\end{array}$ \\
\hline Log (GDP per capita) & $\begin{array}{l}0.8588^{* *} \\
(0.357)\end{array}$ & & $\begin{array}{c}4.4696 \\
(3.775)\end{array}$ \\
\hline 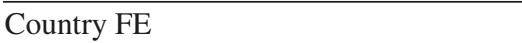 & Yes & Yes & Yes \\
\hline Year FE & Yes & Yes & Yes \\
\hline R-squared & 0.264 & 0.254 & 0.176 \\
\hline Observations & 395 & 395 & 395 \\
\hline Number of countries & 25 & 25 & 25 \\
\hline Cragg-Donald Wald F & 15.77 & 24.02 & 15.77 \\
\hline Kleibergen-Paap rk Wald F & 15.21 & 24.10 & 15.21 \\
\hline Hansen J & 1.552 & 1.510 & 5.584 \\
\hline Prob $>\mathrm{J}$ & 0.670 & 0.680 & 0.134 \\
\hline $\mathrm{C}$ test of endogeneity & 11.22 & 22.70 & 24.86 \\
\hline Prob $>C$ & 0.00367 & $1.18 \mathrm{e}-05$ & $3.99 \mathrm{e}-06$ \\
\hline
\end{tabular}

Notes: The following regressors are omitted from presentation: share of construction in VA, share of industry in VA, share of telecommunications in VA. Robust standard errors appear in parentheses. ${ }^{* * *} \mathrm{p}<0.01,{ }^{* *} \mathrm{p}<0.05,{ }^{*} \mathrm{p}<0.1$. 
It also appears that the productive structure of the economy is a key determinant of tax compliance. In fact, the IV estimates show that an increased share of the real estate sector in the total value added of the economy is associated with lower VAT gaps in all the three specifications. This could be explained by the fact that real estate transactions typically involve substantial amount of money in which case the use of cash is nearly prohibitive, if not actually outlawed. Moreover, those transactions involve extensive paper trail in the form of contracts and land registration.

The results also show some large, positive and significant effects of the dispersion of tax rates on tax evasion. The greater the dispersion, the higher the benefits from a misapplication of reduced rates, which can widen the VAT compliance gap. We report large increases in the VAT gap by 4.15 percentage points of the GDP when the dispersion rate is increased by one unit. When considering an even narrower basis in VTTL, the effect is magnified further to 38 percentage points of the VTTL. These results illustrate the importance of a singular VAT rate within EU countries, as also highlighted in Hopland and Ullman (2019) for the case of Germany. Finally, we report a small, negative and significant association between the deficit to GDP ratio and VAT gaps, suggesting that a one-unit increase of the deficit to GDP ratio will decrease VAT gaps by 0.028 percentage points of the GDP. As stated earlier, ex ante efforts made by tax administrations to close the VAT gap can be driven by the level of public indebtedness. A higher level of deficit would likely pressure tax authorities to take measures that can have a deterrent effect on private agents' tax evasion behavior.

\section{Conclusion}

There is evidence that card payments' traceability could enhance VAT compliance by increasing the perceived probability of detection by the tax authorities which enhances the VAT's deterrence effect (Pomeranz, 2015). This paper investigates the effect of payment methods on valued-added tax compliance in EU countries. It differs from most of the earlier works first by considering a more appropriate measure of the compliance gap that nets out the policy gap given that the entire tax gap is not made up of tax fraud or evasion. Therefore, a concern with these earlier studies is the use of VAT revenue or VRR as measure of tax revenue efficiency without controlling in the regressions for the effect of policy choices on tax structure or the enforcement capacity of the tax administration. Some of these factors cannot be easily accounted for when using aggregate level data, possibly leading to omitted variable bias in the estimates of these papers. Second, even though one of the previous works used the appropriate measures of VAT gap, it examines the effect of one means of payment at a time, a potential for omitted variable bias. In addition, using adequate measures of VAT compliance gap along with more recent data enables us to obtain updated estimates of the relationship between plastic money use and tax compliance.

Using a fixed effect panel data estimation and IV techniques on 26 EU countries from 2000 to 2016, we find some evidence that card payments statistically positively affect tax revenue collection efficiency. At the antipodes of Hondroyiannis and Papaoikonomou (2020) and Madzharova (2020), the OLS results confirm Immordino and Russo (2018a) who find 
that plastic money use does not translate into more VAT revenue collection in a naïve OLS regression. In addition, our study corroborates Madzharova (2020) and Immordino and Russo (2018a) who report that cash transactions are associated with a significant reduction in VAT revenue collected. We argue that our approach provides a more adequate assessment of the relationship between plastic money use and VAT compliance gap relative to Immordino and Russo (2018a) by dealing simultaneously with both means of payments. We also explore a potential endogeneity problem inherent to the choice of a specific means of transactions, which could bias our cross-country analysis. In line with Immordino and Russo (2018a), we find some evidence of the effect of credit and debit card payments on VAT compliance gap. These results suggest that the increased use of plastic money led to gains in consumption tax compliance.

However, the non-significant result for the log specification may require further investigation. To completely close the debate on this topic, a future research program would require micro-level data or administrative records. In other fields, it has been documented that aggregate-level analyses might be limited in power to estimate statistically significant effects (Black et al, 2019). In addition, it would be interesting to explore the impact of the spike in the use of electronic forms of payments due to the exogenous shift in norms in response to COVID-19 which imposed confinement and social distancing. To investigate this, updated VAT gap estimates are needed once member countries' national administrations release their respective end-of-year estimates.

Our results regarding the use of plastic money and especially cash transactions have wider policy implications for both national governments and European authorities. Cash transactions have the property of preserving the anonymity of the payer and recipient and so, despite their overall convenience, they can be used for fraudulent and criminal purposes. As aforementioned, the EU has investigated how cash transactions have not only contributed to fraudulent activities but also to financing terrorism (Europol, 2015). Imposing cash threshold limits has been already introduced in a number of EU countries to combat these problems, but the lack of policy uniformity (for example, a European Union maximum uniform cash threshold) is believed to be adversely affecting the effectiveness of those measures in any country; therefore, the consideration of a uniform standard in the EU. ${ }^{6}$ Based on the adverse impact of (within-country) tax rate dispersion on VAT gaps, it could be argued that the application of a uniform VAT rate has the potential of generating very large reductions in the VAT gap. Lastly, it is worth mentioning that these EU-based findings may very well be generalizable to other countries around the world since they are based on a mix of developed and transition economies. 


\section{Appendix}

\section{Table A1}

SUMMARY STATISTICS AND DATA SOURCES

\begin{tabular}{|c|c|c|c|c|c|c|}
\hline Variables & Source & Max & Min & Mean & Std. Dev. & $\mathbf{N}$ \\
\hline $\begin{array}{l}\text { VAT gap (in EUR } \\
\text { million) }\end{array}$ & $\begin{array}{l}\text { Barbone et al. (2013) and } \\
\text { Poniatowski et al. (2018) }\end{array}$ & 40,424 & 20 & $5,630.30$ & $8,652.70$ & 442 \\
\hline $\begin{array}{l}\text { VAT gap as \% of } \\
\text { VTTL }\end{array}$ & Poniatowski et al. (2018) & 49 & 0 & 16.4522 & 10.2644 & 442 \\
\hline VAT gap as \% of GDP & Poniatowski et al. (2018) & 7.9 & 0 & 1.5903 & 1.2437 & 442 \\
\hline $\begin{array}{l}\text { Card payments as \% } \\
\text { of GDP }\end{array}$ & European Central Bank & 0.46 & 0.001 & 0.11 & 0.08 & 437 \\
\hline $\begin{array}{l}\text { ATM cash withdrawals } \\
\text { as \% of GDP }\end{array}$ & European Central Bank & 0.30 & 0.01 & 0.13 & 0.06 & 413 \\
\hline $\begin{array}{l}\text { Number of ATM per } \\
\text { million inhabitants }\end{array}$ & European Central Bank & 1667.63 & 33.46 & 666.59 & 333.98 & 441 \\
\hline $\begin{array}{l}\text { Share of whole and } \\
\text { retail sale in VA }(\%)\end{array}$ & Eurostat & 32.35 & 10.03 & 20.85 & 3.64 & 442 \\
\hline $\begin{array}{l}\text { Share of real estate in } \\
\text { VA }(\%)\end{array}$ & Eurostat & 19.13 & 4.91 & 9.34 & 2.46 & 442 \\
\hline $\begin{array}{l}\text { Share of construction } \\
\text { in VA }(\%)\end{array}$ & Eurostat & 12.66 & 1.02 & 6.22 & 1.71 & 442 \\
\hline $\begin{array}{l}\text { Share of industry in } \\
\text { VA }(\%)\end{array}$ & Eurostat & 38.58 & 6.15 & 21.33 & 5.6 & 442 \\
\hline $\begin{array}{l}\text { Share of telecommuni- } \\
\text { cation in VA }(\%)\end{array}$ & Eurostat & 10.59 & 3.02 & 4.84 & 1.07 & 442 \\
\hline Share of arts in VA $(\%)$ & Eurostat & 14.57 & 1.4 & 3.07 & 1.41 & 442 \\
\hline Dispersion of tax rates & Poniatowski et al. (2018) & 0.12 & 0 & 0.07 & 0.03 & 442 \\
\hline $\begin{array}{l}\text { Scale of the tax admin- } \\
\text { istration }\end{array}$ & OECD & 0.01 & 0 & 0 & 0 & 304 \\
\hline $\begin{array}{l}\text { IT expenditure over } \\
\text { total administrative } \\
\text { costs }\end{array}$ & OECD & 0.29 & 0 & 0.1 & 0.07 & 208 \\
\hline $\begin{array}{l}\text { Unemployment rate } \\
(\%)\end{array}$ & Eurostat & 27.5 & 1.8 & 8.86 & 4.35 & 442 \\
\hline $\begin{array}{l}\text { Government effective- } \\
\text { ness index }\end{array}$ & World Bank & 2.35 & -0.37 & 1.17 & 0.62 & 416 \\
\hline $\begin{array}{l}\text { Broadband Internet } \\
\text { subscriptions for } 100 \\
\text { people }\end{array}$ & World Bank & 43.10 & 0.01 & 18.96 & 12.13 & 425 \\
\hline Age structure (\%) & Eurostat & 43.2 & 25.7 & 35.15 & 3.37 & 442 \\
\hline $\begin{array}{l}\text { Deficit to GDP ratio as } \\
\% \text { of GDP }\end{array}$ & Eurostat & 6.9 & -32.1 & -2.65 & 3.66 & 442 \\
\hline $\begin{array}{l}\text { GDP per capita (in } \\
\text { EUR) }\end{array}$ & Eurostat & 91,300 & 1,800 & $23,655.91$ & $16,068.98$ & 440 \\
\hline Population (in million) & Eurostat & 82.53 & 0.39 & 19.02 & 23.02 & 442 \\
\hline $\begin{array}{l}\text { Size of the shadow } \\
\text { economy }(\%)\end{array}$ & $\begin{array}{l}\text { Medina and Schneider } \\
(2018)\end{array}$ & 35.30 & 7.69 & 18.13 & 6.72 & 416 \\
\hline
\end{tabular}


Table A2

FIXED-EFFECT PANEL REGRESSION ESTIMATES OF VAT GAP ON PLASTIC MONEY USE INCLUDING CEE COUNTRY INDICATOR

\begin{tabular}{|c|c|c|c|c|c|c|}
\hline \multirow[b]{2}{*}{$\begin{array}{l}\log (\text { Card payments as \% } \\
\text { of GDP })\end{array}$} & \multicolumn{2}{|c|}{ Log (VAT gap) } & \multicolumn{2}{|c|}{$\begin{array}{c}\text { VAT gap as \% of } \\
\text { GDP }\end{array}$} & \multicolumn{2}{|c|}{$\begin{array}{l}\text { VAT gap as \% of } \\
\text { VTTL }\end{array}$} \\
\hline & $\begin{array}{c}0.0482 \\
(0.137)\end{array}$ & $\begin{array}{c}0.0734 \\
(0.320)\end{array}$ & $\begin{array}{c}0.1030 \\
(0.155)\end{array}$ & $\begin{array}{c}0.4390 \\
(0.276)\end{array}$ & $\begin{array}{c}0.5584 \\
(1.566)\end{array}$ & $\begin{array}{l}4.2218 \\
(2.594)\end{array}$ \\
\hline $\begin{array}{l}\log (\text { ATM cash withdraw- } \\
\text { als as } \% \text { of GDP) }\end{array}$ & $\begin{array}{l}-0.0887 \\
(0.224)\end{array}$ & $\begin{array}{l}-0.0863 \\
(0.228)\end{array}$ & $\begin{array}{l}-0.1500 \\
(0.140)\end{array}$ & $\begin{array}{l}-0.1119 \\
(0.151)\end{array}$ & $\begin{array}{l}-2.5835 \\
(1.654)\end{array}$ & $\begin{array}{l}-2.2439 \\
(1.740)\end{array}$ \\
\hline $\begin{array}{l}\log (\text { Card payments as } \% \\
\text { of GDP) x CEE dummy }\end{array}$ & & $\begin{array}{l}-0.0286 \\
(0.320)\end{array}$ & & $\begin{array}{l}-0.3495 \\
(0.292)\end{array}$ & & $\begin{array}{l}-4.1581 \\
(3.063)\end{array}$ \\
\hline $\begin{array}{l}\text { Share of whole and retail } \\
\text { sale in VA }(\%)\end{array}$ & $\begin{array}{l}-0.0148 \\
(0.030)\end{array}$ & $\begin{array}{l}-0.0152 \\
(0.030)\end{array}$ & $\begin{array}{l}-0.0562 \\
(0.056)\end{array}$ & $\begin{array}{l}-0.0617 \\
(0.054)\end{array}$ & $\begin{array}{c}0.0526 \\
(0.391)\end{array}$ & $\begin{array}{c}0.0064 \\
(0.377)\end{array}$ \\
\hline $\begin{array}{l}\text { Share of real estate in VA } \\
(\%)\end{array}$ & $\begin{array}{l}-0.0614 \\
(0.055)\end{array}$ & $\begin{array}{l}-0.0619 \\
(0.057)\end{array}$ & $\begin{array}{l}-0.0195 \\
(0.056)\end{array}$ & $\begin{array}{l}-0.0271 \\
(0.054)\end{array}$ & $\begin{array}{l}-0.1995 \\
(0.510)\end{array}$ & $\begin{array}{l}-0.2761 \\
(0.503)\end{array}$ \\
\hline Share of arts in VA (\%) & $\begin{array}{l}-0.0754 \\
(0.064)\end{array}$ & $\begin{array}{l}-0.0780 \\
(0.075)\end{array}$ & $\begin{array}{r}0.0347 \\
(0.055)\end{array}$ & $\begin{array}{r}0.0066 \\
(0.057)\end{array}$ & $\begin{array}{c}0.0372 \\
(0.530)\end{array}$ & $\begin{array}{l}-0.3384 \\
(0.584)\end{array}$ \\
\hline Dispersion of tax rates & $\begin{array}{l}-0.7873 \\
(1.814)\end{array}$ & $\begin{array}{l}-0.8202 \\
(1.806)\end{array}$ & $\begin{array}{c}2.5325 \\
(1.940)\end{array}$ & $\begin{array}{r}2.1210 \\
(1.859)\end{array}$ & $\begin{array}{c}26.1645 \\
(18.965)\end{array}$ & $\begin{array}{l}21.3974 \\
(18.681)\end{array}$ \\
\hline Unemployment rate & $\begin{array}{c}0.0241 \\
(0.014)\end{array}$ & $\begin{array}{c}0.0240 \\
(0.015)\end{array}$ & $\begin{array}{l}0.0554^{* *} \\
(0.023)\end{array}$ & $\begin{array}{l}0.0526^{* *} \\
(0.025)\end{array}$ & $\begin{array}{l}0.4771^{* *} \\
(0.206)\end{array}$ & $\begin{array}{l}0.4628^{* *} \\
(0.210)\end{array}$ \\
\hline Age structure & $\begin{array}{c}0.0750 \\
(0.051)\end{array}$ & $\begin{array}{c}0.0750 \\
(0.052)\end{array}$ & $\begin{array}{l}0.1367^{* *} \\
(0.059)\end{array}$ & $\begin{array}{l}0.1369^{* *} \\
(0.060)\end{array}$ & $\begin{array}{l}1.0273^{*} \\
(0.561)\end{array}$ & $\begin{array}{l}1.0295^{*} \\
(0.567)\end{array}$ \\
\hline $\begin{array}{l}\text { Deficit to GDP ratio as \% } \\
\text { of GDP }\end{array}$ & $\begin{array}{l}-0.0297 \\
(0.019)\end{array}$ & $\begin{array}{l}-0.0297 \\
(0.019)\end{array}$ & $\begin{array}{l}-0.0323^{*} \\
(0.018)\end{array}$ & $\begin{array}{l}-0.0328^{*} \\
(0.018)\end{array}$ & $\begin{array}{l}-0.3296^{*} \\
(0.176)\end{array}$ & $\begin{array}{l}-0.3217^{*} \\
(0.177)\end{array}$ \\
\hline Log(Population) & $\begin{array}{l}-0.3827 \\
(2.548)\end{array}$ & $\begin{array}{l}-0.4238 \\
(2.570)\end{array}$ & $\begin{array}{r}1.0475 \\
(1.728)\end{array}$ & $\begin{array}{r}0.2753 \\
(1.739)\end{array}$ & $\begin{array}{r}8.0680 \\
(17.840)\end{array}$ & $\begin{array}{r}2.1029 \\
(18.689)\end{array}$ \\
\hline Log(GDP per capita) & $\begin{array}{c}0.9493^{*} \\
(0.463)\end{array}$ & $\begin{array}{c}0.9645^{*} \\
(0.509)\end{array}$ & & & $\begin{array}{r}1.8887 \\
(3.817)\end{array}$ & $\begin{array}{l}4.1014 \\
(4.454)\end{array}$ \\
\hline Country FE & Yes & Yes & Yes & Yes & Yes & Yes \\
\hline Year FE & Yes & Yes & Yes & Yes & Yes & Yes \\
\hline Observations & 412 & 412 & 412 & 412 & 412 & 412 \\
\hline R-squared & 0.317 & 0.317 & 0.314 & 0.318 & 0.286 & 0.292 \\
\hline Number of countries & 26 & 26 & 26 & 26 & 26 & 26 \\
\hline
\end{tabular}

Notes: The following regressors are omitted from presentation: share of construction in VA, share of industry in VA, share of telecommunications in VA, $\log$ (population) and the constant term. Robust standard errors appear in parentheses. ${ }^{* * *} \mathrm{p}<0.01,{ }^{* *} \mathrm{p}<0.05,{ }^{*} \mathrm{p}<0.1$. 


\section{Notes}

1. The Consultation Strategy of the European Commission on February 22016 (European Commission, 2016) and the Opinion of the European Central Bank of 30 December 2019 (CON/2019/46) on limitations to cash payments can be accessed here: https://ec.europa.eu/info/sites/info/files/consultation_strategy_final.pdf and here: https://eur-lex.europa.eu/legal-content/EN/TXT/PDF/?uri=CELEX:52019AB0046\&from=EN.

2. Albeit not relevant to the tax compliance focus of this paper, it is important to note that the documented rise in the digital payments could have adverse distributional effects on the unbanked and vulnerable populations (Auer et al., 2020).

3. The estimated VAT gaps are defined as the difference between expected VAT revenues according to the law and actual VAT collections. This includes "foregone VAT revenue from to tax fraud, tax evasion and tax avoidance. Moreover, the tax gap also incorporates revenues losses from bankruptcies, financial insolvency and errors" (source: https://ec.europa.eu/taxation_customs/business/tax-cooperation-control/vat-gap_en).

4. A more precise proxy for cash transactions would be the sum of the value of Automatic Teller Machine (ATM), Over-The-Counter (OTC), and Point-Of-Sale (POS) cash withdrawals. However, there are a lot of missing values on these variables for each country at different points in time. Hence, the total cash transactions constructed as the sum of ATM, OTC, and POS withdrawals may not be a good proxy for cash transactions.

5. For all countries but Bulgaria, Luxembourg, Slovakia, and Spain, data on plastic money use are available from 2000. For Bulgaria, Luxembourg, and Slovakia, these data stem from 2001. For Spain, they start from 2002.

6. For the list of cash payment limit thresholds in the EU, see: https://www.europe-consommateurs.eu/fileadmin/ user_upload/eu-consommateurs/PDFs/PDF_EN/Limit_for_cash_payments_in_EU.pdf.

\section{References}

Agha, A. and Haughton, J. (1996), "Designing VAT systems: Some efficiency considerations", Review of Economics and Statistics, 78(2): 303-308.

Auer, R., Cornelli, G. and Frost, J. (2020), “Covid-19, cash, and the future of payments”, Bank for International Settlements, BIS Bulletins 3.

Barbone, L., Belkindas, M., Bettendorf, L., Bird, R., Bonch-Osmolovskiy, M. and Smart, M. (2013), "Study to quantify and analyse the VAT Gap in the EU-27 Member States", Final Report of project TAXUD/2012/DE/316.

Black, B., Hollingsworth, A., Nunes, L. and Simon, K. (2019), The effect of health insurance on mortality: Power analysis and what we can learn from the affordable care act coverage expansions, NBER, w25568.

Christie, E. and Holzner, M. (2006), "What Explains Tax Evasion? An Empirical Assessment Based on European Data", The Vienna Institute for International Economic Studies, Working Papers, 40.

European Commission (2016), Communication from the Commission to the European Parliament and the Council on an Action Plan for Strengthening the Fight against Terrorist Financing, COM(2016) 50 final.

Europol (2015), "Why is cash still king? A strategic report on the use of cash by criminal groups as a facilitator for money laundering", Trends in Organized Crime, 18: 355-379.

Godin, M. and Hindriks, J. (2015), "A review of critical issues on tax design and tax administration in a global economy and developing countries", CRED-UNamur, Working Paper 7. 
Hondroyiannis, G. and Papaoikonomou, D. (2017), "The effect of card payments on VAT revenue: New evidence from Greece", Economics Letters, 157: 17-20.

Hondroyiannis, G. and Papaoikonomou, D. (2020), "The effect of card payments on VAT revenue in the euro area: Evidence from a panel VECM", Journal of Economics Studies, Vol. ahead-of-print No. ahead-of-print, https://doi.org/10.1108/JES-03-2019-0138.

Hopland, A. O. and Ullmann, R. (2019), "Pushing the wrong buttons: VAT evasion by misclassification of meal consumption type", European Accounting Review, 1-23.

Humphrey, D., Willesson, M., Bergendahl, G. and Lindblom, T. (2006), "Benefits from a changing payment technology in European banking", Journal of Banking and Finance, 30(6): 1631-1652.

Immordino, G. and Russo, F. F. (2018a), "Cashless payments and tax evasion”, European Journal of Political Economy, 55: 36-43.

Immordino, G. and Russo, F. F. (2018b), "Fighting Tax Evasion by Discouraging the Use of Cash?", Fiscal Studies, 39(2): 343-364.

Kleven, H. J., Knudsen, M. B., Kreiner, C. T., Pedersen, S. and Saez, E. (2011), "Unwilling or unable to cheat? Evidence from a tax audit experiment in Denmark", Econometrica, 79(3): 651-692.

Koumpias, A. M., Leonardo, G. and Martínez-Vázquez, J. (2021), “Trust in Government Institutions and Tax Morale”, FinanzArchiv (FA), 77(2): 117-140.

Lago-Peñas, I. and Lago-Peñas, S. (2010), “The determinants of tax morale in comparative perspective: Evidence from European countries”, European Journal of Political Economy, 26: 441-453.

Madzharova, B. (2020), “Traceable payments and VAT design: Effects on VAT performance”, CESifo Economic Studies, 66(3): 221-247.

Medina, L. and Schneider, F. (2018), "Shadow economies around the world: What did we learn over the last 20 years?”, IMF, Working Paper WP/18/17: 1-76.

Morse, S. C., Karlinsky, S. and Bankman, J. (2009). "Cash businesses and tax evasion”, Stanford Law \& Policy Review, 20: 37.

OECD (2017), Tax administration 2017: Comparative information on OECD and other advanced and emerging economies, Paris: OECD Publishing.

OECD (2019), Money laundering and terrorist financing awareness handbook for tax examiners and tax auditors, Paris: OECD Publishing.

Otranto, E., Pisani, S. and Polidoro, F. (2003), "Un modello statistico per comprendere le determinanti dell'evasione", in R. Convenevole and S. Pisani, "Le basi imponibili IVA Un'analisi del periodo 1982-2001", Agenzia Entrate, Working Paper 2003/1.

Pomeranz, D. (2015), "No taxation without information: Deterrence and self-enforcement in the value added tax", American Economic Review, 105(8): 2539-2569.

Poniatowski, G., Bonch-Osmolovskiy, M., Durán-Cabré, J. M. and Esteller-Moré, A. (2018), "Study and reports on the VAT gap in the EU-28 member states: 2018 final report", Report of project TAXUD/ 2015/CC/131.

Reckon (2009), "Study to quantify and analyse the VAT gap in the EU-25 member states", Report of project TAXUD. 
Schneider, F. (2012), “The shadow economy and tax evasion: What do we (not) know?", CESifo Forum, 13(2): 3-12.

Slemrod, J., Collins, B., Hoopes, J. L., Reck, D. and Sebastiani, M. (2017), “Does credit-card information reporting improve small-business tax compliance?", Journal of Public Economics, 149: 1-19.

Stepner, M. (2014), "Binned scatterplots: introducing -binscatter- and exploring its applications", Stata Users Group, Stata Conference 4.

Stock, J. and Yogo, M. (2005), “Testing for Weak Instruments in Linear IV Regression”. In: Andrews DWK, Identification and Inference for Econometric Models, New York: Cambridge University Press, 80-108.

\section{Resumen}

Este trabajo examina el impacto de la utilización de tarjetas de crédito y de débito sobre el cumplimiento en los impuestos sobre el consumo. Se utilizan datos anuales a nivel nacional para 26 países de la Unión Europea entre 2000 y 2016. Explotando la variación espacio-temporal en los pagos con tarjeta, mediante un enfoque de variables instrumentales, encontramos que un aumento del $1 \%$ en los mismos reduce 0,51 puntos porcentuales la brecha fiscal (tax gap) del IVA, mientras que un aumento del $1 \%$ en los retiros de efectivo la aumenta en 0,6 puntos porcentuales. Nuestra contribución consiste en utilizar medidas más adecuadas del indicador de la brecha de cumplimiento en el IVA teniendo en cuenta otros posibles determinantes, tal como la capacidad de garantizar ex ante el cumplimiento fiscal por parte de las administraciones tributarias.

Palabras clave: cumplimiento fiscal, uso de tarjetas de crédito y débito, brecha del IVA, administración tributaria.

Clasificación JEL: H26, K42. 